\title{
PENGGUNAAN BAHASA INDONESIA LISAN BAIK DAN BENAR DALAM KELOMPOK KECIL KALANGAN MAHASISWA PRODI BAHASA DAN SASTRA INDONESIA UNIVERSITAS VICTORY SORONG
}

\author{
Irwan soulisa \\ Universitas Victory Sorong \\ Email: Soulisairwan@gmail.com
}

\begin{abstract}
Abstrak
Penelitian ini menggunakan metode kualitatif deskriptif dengan teknik pengumpulan data melalui observasi, wawancara tak berstuktur bertujuan untuk mengetahui penggunaan bahasa Indonesia lisan baik dan benar kalangan mahasiswa Prodi Pendidikan Bahasa dan Sastra Indonesia Universitas Victory Sorong tahun 2018. Teknik analisis data secara deskriptif kualitatif, mencakup analisis proses dan analisis data produk Validitas yang digunakan dalam penelitian ini validitas demokratik. Hasil penelitian menyatakan bahwa penggunaan kemampuan berbicara lisan Bahasa Indonesia baik dan benar kalangan mahasiswa prodi bahasa dan sastra Indonesia Unvic Sorong dari 14.30 menjadi 26.36, meningkat sebesar 12.06 atau 84.33\%. Perubahan terjadi pada aspek pilihan kata, yaitu dari 1.56 menjadi 2.83 atau mengalami kenaikan 1.27 atau $81.41 \%$. Perubahan juga terjadi pada aspek struktur yaitu dari 1.36 menjadi 2.63 atau mengalami kenaikan 1.27 atau 93. 38\%. Perubahan juga terjadi pada aspek pelafalan yaitu dari 1.36 menjadi 2.70, naik1.14 atau 98.52\%.Pada aspek intonasi naik dari 2.86 menjadi 5.20 artinya mengalami kenaikan sebesar 2.34 atau $81.88 \%$. Pada aspek sikap wajar tenang dan tidak kaku naik dari 1.50 menjadi 2.63 artinya mengalami kenaikan sebesar 1.13 atau $75.33 \%$. Pada aspek penguasaan medan naik dari 1.53 menjadi 2.66 atau mengalami kenaikan sebesar 1.13 atau $75.85 \%$. Pada aspek penguasaan materi naik dari 2.66 menjadi 5.13 atau mengalami kenaikan sebesar 2.47 atau $92.85 \%$. Kemudian pada aspek gerak-gerik dan mimic mengalami kenaikan dari 1.43 menjadi 2.70 atau naik sebesar 1.13 atau $79.02 \%$.
\end{abstract}

Kata kunci: Bahasa Indonesia Lisan, baik dan benar, dalam kelompok kecil.

\begin{abstract}
This research in a qualitative descriptive to technique data collection through observation, interview not berstuktur aims to know the use of indonesian language spoken good and right among students prodi education language and literature indonesia university victory mizzen mizzen 2018 .Technique analysis data is descriptive qualitative which includes analysis the process and analysis of data products validity used in this research validity of democratic.The results of the study states that the use of the ability to speak oral indonesian language good and right among students prodi language and literature indonesia unvic mizzen of $2.30 \mathrm{pm}$ be 26.36 , increased by 12.06 or $84.33 \%$.The change occurred on the the chosen word, from 1.56 be 2.83 or increased 1.27 or $81.41 \%$. Changes also happened on the structure from 1.36 be 2.63 or increased 1.27 or $93.38 \%$.Changes also happened on the pronunciation from 1.36 be 2.70 , naik1.14 or $98.52 \%$.pada aspects intonation up from 2.86 be 5.20 it means increased by 2.34 or $81.88 \%$. On the attitude reasonable calm and not stiff up from 1.50 be 2.63 it means increased by 1.13 or $75.33 \%$.On the mastery medan up from 1.53 be 2.66 or increased by 1.13 or $75.85 \%$.On the their mastery of the material up from 2.66 be 5.13 or increased by all 2.47 or $92.85 \%$. Then on the behaviors and mimic has increased from 1.43 be 2.70 or an increase of 1.13 or $79.02 \%$
\end{abstract}

Keywords: Indonesian language spoken, good and right, small groups .

\section{PENDAHULUAN}

Keterampilan berbahasa tidak dapat diperoleh melalui kegiatan menghafal. Keterampilan berbahasa bukanlah sesuatu yang dapat diajarkan melalui uraian atau penjelasan semata. Mahasiswa tidak dapat memperoleh keterampilan berbahasa hanya dengan duduk dan mendengar keterangan atau penjelasan dari pendidik. Keterampilan berbahasa dapat diperoleh dengan melakukan kegiatan berbahasa secara terus menerus. 
Pengajaran keterampilan berbicara juga perlu mencakup (1) kenyaringan suara, (2) kelancaran, (3) sikap berbicara, (4) gerak-gerik mimik muka, (5) penalaran, (6) santun berbicara. Kemampuan berbicara mahasiswa, dapat dilakukan saat kegiatan berbicara dalam mengespresikan diri melalui kelompok kecil diharapkan kemampuan berbahasa mahasiswa berkembang khususnya kemampuan berbicara. Selama periode usia sekolah kognitif meningkat pesat sehingga memungkinkan anak menjadi komunikatif yang efektif.

Kemampuan berbicara mahasiswa pada semester satu perlu ditingkatkan. Dalam hal ini upaya kemampuan berbicara tersebut dapat berhasil baik atau tidak tergantung kepada upaya pendidik, metode pengajar yang digunakan, serta mahasiswa sebagai objek.

Di samping penguasaan materi pelajaran, pendidik hendaknya mempunyai pengalaman yang beraneka ragam tentang metode mengajar atau teknik mengajar. Dosen bahasa Indonesia yang mengetahui aneka ragam teknik pengajar keterampilan berbahasa dan dapat mempraktikannya sangat membantu dalam mengajarkan keterampilan berbahasa. Pengajar atau dosen yang memiliki pengetahuan luas, mampu memimpin mahasiswa untuk memecahkan masalah yang kompleks. Dosen melontarkan kepada mahasiswa untuk dianalisis, pada tiap-tiap kelompok dapat mendiskusikan apa yang disampaikan oleh dosen (Roestiayah. N.K, 2008: 157).

Pengajaran yang tidak tepat dapat menyebabkan mahasiswa tidak seimbang dalam kemampuan teoretis dan praktisnya serta kurang kreatif. Hal ini juga disebabkan oleh beberapa faktor, seperti dosen, bahan pelajaran, kesiapan mahasiswa, dan sarana pengajar. Ketidakseimbangan dalam faktorfaktortersebut dapat berdampak pada hasil pengajaran bahasa. Kurangnya sarana dan prasarana mengakibatkan penyampaian materi informasi dalam proses belajar mengajar kurang lancar dan tidak efektif.

Pengajaran kemampuan berbicara untuk mahasiswa saat sekarang kurang sekali. Sistem pengajaran pada waktu dulu banyak memberikan motivasi mahasiswa dalam mengembangkan keterampilan berbicara melalui mendengarkan cerita yang diberikan oleh dosen. Dengan mendengarkan cerita mahasiswa dapat menambah wawasan serta imajinasi mereka. Berbeda dengan sekarang, dosen sedikit sekali dalam memberikan ilmu dan pengetahuan melalui berbicara. Selain itu, yang menjadi faktor kurangnya pengetahuan tentang berbicara adalah faktor orang tua. Pada saat ini jarang sekali orang tua yang dapat memberikan sedikit berbicara kepada anaknya dalam suasana santai. Pada zaman dahulu orang tua selalu memberikan tatacara berbicara sebagai arahan atau petunjuk kepada anaknya, tetapi seiring perkembangan zaman anak selalu dimanjakan oleh teknologi yang serba maju.

Dalam keterampilan berbahasa pendidik harus dapat mengajarkan materi tentang keterampilan berbahasa kepada mahasiswa. Sebaiknya pendidik keterampilan berbahasa hendaknya tidak 
menggunakan pola lama dalam mengajar mahasiswa, yakni pola mengajar secara rutin, monoton tanpa bervariasi; sehingga mahasiswa kurang mendapatkan variasi berbicara dalam memperoleh pelajaran di kelas. Di pihak lain, orang tua sebagai komponen penting yang dapat mempengaruhi keterampilan berbahasa pada anak. Orang tua hendaknya dapat memberikan suatu keterampilan berbahasa lewat kegiatan berbicara kepada anak.

\section{KAJIAN TEORI}

Upaya pendidik menggunakan bahasa Indonesia lisan baik dan benar dalam kelompok kecil Prodi Bahasa dan Sastra Indonesia Unvic Sorong kalangan mahasiswa melalui kemampuan berbicara dapat menggunakan beberapa metode pengajaran berbicara. Banyak metode yang dapat digunakan oleh pengajar dalam kemampuan berbicara. Metode tersebut antara lain pendidik menggunakan kegiatan berbicara dengan kelompok kecil dan pendidik sebagai pelatih, sehingga proses pendidikan dan pembelajaran memerlukan latihan keterampilan, baik intelektual maupun motorik, yang menuntut pendidik untuk bertindak sebagai pelatih. Pelatihan yang dilakukan, disamping harus memperhatikan kompetensi dasar, juga harus memperhatikan perbedaan individual peserta didik dan lingkungannya (Muslikah, 2010: 19).

Untuk mengetahui seberapa jauh penggunaan kemampuan berbicara bahasa Indonesia lisan baik dan benar kalangan mahasiswa, dapat dilakukan kegiatan berbicara dalam kelompok kecil, khususnya dalam pelajaran bahasa Indonesia. Melalui kegiatan berbicara dalam kelompok kecil diharapkan kemampuan berbahasa mahasiswa dapat lebih maju. Selama duduk dalam bangku perkuliahan diharapkan mahasiswa menjadi komunikator yang baik, hal itu sering dengan tingkat perkembangan proses kognitif.

Melihat kenyataan yang ada di lapangan selama ini sikap kerja sama dalam kelompok mahasiswa belum memuaskan. Kerja sama dalam kelompok masih diterapkan dalam diskusi dan belum diterapkan pada kegiatan lain. Ini disebabkan oleh beberapa hal antara lain kurangnya variasi dosen dalam menyampaikan materi perkuliahan seperti tugas secara kelompok, ada perbedaan secara individual serta diperkirakan pemahaman dan minat belajar mahasiswa terhadap mata pelajaran Bahasa dan Sastra Indonesia masih kurang.

Kondisi tersebut mendorong peneliti untuk senantiasa berupaya menvariasikan penggunaan metode yang dapat melatih mahasiswa bekerja sama dengan mahasiswa lain di antaranya metode kerja kelompok hanya dapat diskusi saja. Oleh karena itu, penulis mencoba mengunakan metode kerja kelompok dalam kegiatan berbicara dalam kelompok kecil untuk mempertinggi hasil belajar baik secara kualitatif maupun kuantitatif, dan untuk membantu mahasiswa menjadi manusia demokratis (Nasution, 2010: 147).

Pada umumnya mahasiswa lebih menyukai proses pembelajaran yang melibatkan dirinya. Mereka diberikan kebebasan untuk memberi respon terhadap apa yang diterimanya. Dengan cara demikian, 
sikap kerja sama dalam kelompok dalam pembelajaran bahasa Indonesia dapat mengatasi segala kekurangan yang ada.

Berdasarkan hasil pengamatan peneliti, Banyak hal yang mempengaruhinya, baik dari pihak pendidik maupun mahasiswa. Mahasiswa kurang memahami terhadap peran benar khususnya dalam keterampilan berbicara. Penentuan materi serta metode pengajaran yang kurang tepat, dan minimnya bahan bacaan. Oleh karena itu, melalui penelitian ini peneliti akan mendeskripsikan upaya tentang kemampuan berbicara Bahasa Indonesia baik dan benar dalam kelompok kecil pada prodi pendidikan bahasa dan sastra Indonesia Universitas Victory Sorong.

\section{METODE PENELITIAN}

Metode penelitian yang diperlukan dalam pencapaian sasaran penelitian karena metode yang merumuskan ide dan pikiran yang didasarkan pada pendekatan ilmiah. Metode kualitatif sebagai prosedur penelitian yang menghasilkan data deskriptif berupa kata-kata tertulis atau lisan dari orang-orang dan perilaku yang dapat diamati Pendekatan ini diarahkan pada latar dan individu tersebut secara holistik (Sugiyono, 2014).

Pendekatan yang digunakan adalah penelitian tindakan, yakni penelitian tindakan kelas (PTK) prosedur penelitian meliputi kegiatan sebelum pelaksanaan berupa refleksi awal dan observasi untuk mengidentifikasi masalah yang terjadi di prodi pendidikan bahasa dan sastra Indonesia di kelas/ruangan, dilanjutkan dengan pelaksanaan sebanyak dua tahap.
Penelitian ini menggunakan teknik purposive sampling.

Subjek penelitian diambil sesuai dengan tujuan atau permasalahan yang dikaji berdasarkan kebutuhan penelitian. Penelitian ini menggunakan teknik pengumpulan data berupa observasi, wawancara, dan dokumen. Analisis data dilakukan menggunakan analisis isi/konten yang diaplikasikan dalam semua kerangka kerja analisis penelitian deskriptif-kualitatif. Langkah-langkah analisis meliputi, analisis setiap komponen, reduksi data, penyajian data, dan penarikan simpulan.

\section{HASIL PENELITIAN}

\section{Hasil Obsevasi Siklus I}

Berdasarkan hasil observasi terhadap kegiatan pendidik dalam melaksanakan perkuliahan yang dinilai dari empat aspek, yakni (1) membuka perkuliahan, (2) melaksanakan kegiatan inti perkuliahan, (3) refleksi, dan penilaian (4) faktor penunjang yang meliputi penggunaan bahasa Indonesia lisan baik dan benar serta percaya diri.

Berdasarkan hasil penelitian perkuliahan dalam hal ini pembelajaran yang diperoleh nilai yang dapat disimpulkan bahwa penggunaan bahasa Indonesia lisan baik dan benar kalangan mahasiswa prodi pendidikan bahasa dan sastra Indonesia dalam kelompok kecil Unvic Sorong semester satu secara rata-rata dalam katagori kurang pada aspek kebahasaan antara lain (1) aspek pilihan kata dengan nilai ratarata 1,56 (2) aspek struktur dengan nilai rata-rata 1,36 (3) aspek pelafalan dengan nilai rata-rata 1,36 (4) aspek intonasi dengan nilai ratarata 2,86 dan pada aspek 
nonkebahasaan anatara lain (1) aspek sikap jujur,tenang, dan tidak kaku dengan nilai rata-rata 1,50 (2) aspek penguasaan medan nilai ratarata 1,53 (3) aspek penguasaan materi dengan nilai rata-rata 2,66 (4) aspek gerak gerik/mimik dengan nilai rata-rata 1,43 . Secara umum mahasiswa masih perlu meningkatkan inovasi pembelajaran dalam penggunaan bahasa Indonesia lisan baik dan benar melalui aspek kebahasaan dan aspek non kebahasaan yang mengarah pada perubahan penggunaan bahasa di kalangan mahasiswa Prodi Bahasa dan Sastra Indonesia Unvic Sorong.

\section{Refleksi tahap I}

Refleksi dilakukan dengan diskusi bersama anatara peneliti dengan dosen. Dalam kegiatan ini peneliti menyampaikan kelebihan dan kelemahan dari masing-masing mahasiswa dalam pelaksanaan pembelajaran penggunaan bahasa Indonesia lisan baik dan benar dalam kelompok kecil. Dalam refleksi disampaikan kekurangan kesalahan-kesalahan dari masingmasing mahasiswa, sehingga dapat digunakan sebagai evaluasi diri. Hasil refleksi digunakan untuk perbaikan pembelajaran pada tahap ke dua.

\section{Hasil Observasi Tahap II}

Setelah perkuliahan dan pembelajaran berakhir peneliti mengadakan diskusi dengan dosen untuk mengetahui temuan-temuan selama kegiatan pembelajaran perkulihaan berlangsung, dan kendala-kendala yang dihadapi dalam proses kegiatan belajar mengajar (KMB). Nilai dari masingmasing mahasiswa, dengan rata-rata mengalami perubahan pada tahap kedua dengan nilai yang diperoleh berdasarkan aspek kebahasaan, yakni aspek pilihan kata dengan nilai rata-rata 2,10 (2) aspek struktur dengan nilai rata-rata 1,86 (3) aspek pelafalan dengan nilai rata-rata 1,36 (4) aspek intonasi dengan nilai ratarata 2,86 dan aspek non kebahasaan anatara lain (1) aspek sikap wajar, tenang, dan tidak kaku nilai rata-rata 1,90 (2) aspek penguasaan medan 1,90 (3) aspek penguasaan materi nilai rata-rata 3,33 (4) aspek gerak gerik/mimik nilai rata-rata 1,86 . Dilihat dari nilai rata-rata dari semua aspek penggunaan bahasa Indonesia lisan baik dan benar dalam kelompok kecil meningkat dibandingkan tahap pertama.

\section{Refleksi tahap II}

Kegiatan refleksi dilaksanakan pada akhir pertemuan tahap II. Tahap ini merupakan tahap pengamatan secara rinci, segala hal yang terjadi di kelas atau ruangan selama kegiatan pembelajaran atau perkuliahan baik berupa aktivitas mahasiswa maupun dosen. Hasil refleksi selama pembelajaran atau perkuliahan pada tahap II disampaikan kepada masing-masing mahasiswa baik temuan yang berupa kelemahan maupun kelebihan, yang selanjutnya digunakan sebagai dasar rencana tindak lanjut pada pembelajaran atau perkuliahan di lain waktu, dan digunakan sebagai dasar saran pelaksanaan penggunaan kemampuan berbahasa Indonesia lisan baik dan benar kalangan mahasiswa prodi pendidikan bahasa dan sastra Indonesia di lapangan.

\section{PEMBAHASAN}

Berdasarkan hasil yang diperoleh dari pelaksanaan tindakan pada tahap satu dan tahap dua dapat 
dilihat bahwa ada kenaikan nilai rata-rata yang diperoleh dari masing-masing aspek kebahasaan dan non kebahasaan di kalangan mahasiswa Prodi Bahasa dan Sastra Indonesia Unvic Sorong. Hal ini sesuai dengan tujuan, yakni kemampuan penggunaan bahasa Indonesia lisan baik dan benar dikalangan mahasiswa.

Bila dibandingkan dengan nilai yang diperoleh secara rata-rata pada tahap pertama untuk seluruh aspek kebahasaan dan non kebahasaan adalah 14,69 dan nilai yang diperoleh pada tahap kedua rata-rata untuk seluruh aspek kebahasaan dan non kebahasaan sebesar 18,25 maka, mengalami perubahan yang cukup signifikan, yaitu sebesar 4,38. Artinya dengan pelaksanaan penggunaan setiap aspek kebahasaan dan non kebahasaan penggunaan bahasa Indonesia lisan baik dan benar dalam kelompok kecil prodi pendidikan bahasa dan sastra Indonesia Unvic Sorong mengalami perubahan atau peningkatan nilai rata-rata mahasiswa sebesar 4,38.

\section{SIMPULAN}

Berdasarkan temuan dari hasil pelaksanaan tindakan dan didukung dengan penelitian terdahulu dan berbagai pendapat pakar, dapat disimpulkan bahwa penggunaan bahasa Indonesia lisan baik dan benar kalangan mahasiswa Prodi Bahasa dan Sastra Indonesia Unvic Sorong dapat meningkatkan kompetensi pendidik dan mahasiswa terutama dalam penggunaan aspek kebahasaan dan aspek nonkebahasaan.

\section{SARAN}

Berdasarkan hasil penelitian pada mahasiswa prodi pendidikan bahasa dan sastra Indonesia Unvic Sorong, dengan hasil bahwa kalangan mahasiswa dapat meningkatkan penggunaan bahasa Indonesia lisan baik dan benar. Oleh karena itu, penulis memberi saran sebagai berikut.

1) Untuk mengembangkan kemampuan penggunaan bahasa Indonesia diperlukan sikap dan keterampilan dalam menyampaikan pendapat, menjawab pertanyaan memerlukan banyak latihan.

2) Pendidik perlu melakukan pendekatan untuk memberi motivasi sehingga terbentuk rasa percaya diri pada kalangan mahasiswa Prodi Bahasa dan Sastra Indonesia Unvic Sorong.

3) Perubahan tingkah laku merupakan tujuan pembelajaran yang digunakan oleh peserta didik sebagai terapan dan pengembangan kemampuan berbicara.

4) Nilai sikap belajar untuk mengetahui respon mahasiswa terhadap materi belajar digunakan untuk salah satu bahan intropeksi seorang pendidik terhadap usaha-usaha yang dilakukan dalam proses pembelajaran 


\section{DAFTAR PUSTAKA}

Artati,b.2010. Panduan Pendidikan Bahasa Indonesia. Klaten: Intan Pariwara.

Arikunto, S. 2010. Penelitian Belajar Mengajar. Jogjakarta: Aditya Media.

Emzir.2010. Metodologi Penelitian Pendidikan Kuantitatif dan Kualitatif. Jakarta:

Grapindo Persada.

Gorys, 1969.Tata Bahasa Indonesia.Jakarta: Nusa Indah.

Gorys. 1970.Komposisi. Jakarta: Nusa Indah.

Kerap, G. 1987. Diksi dan Gaya Bahasa.Jakarta: PT Gramedia.

Muslikah.2010. Sukses Profesi Guru.Jogjakarta: Kelompok Penerbit Pinus.

Muslich. 2008. Fonologi Bahasa Indonesia. Jakarta: Bumi Aksara.

Nasution.2010. Didaktis Asas-Asas Mengajar.Jakarta: Bumi Aksara.

Rostiyah.N.K. 2008.Strategi Belajar Mengajar. Jakarta: Rineka Cipta.

Restuti, E. 2006.Bahasa Indonesia Kelas VII.Jakarta: Erlangga.

Sri Ningsih, DKK. 2008. Bahasa Indonesia Kelas I. Klaten: Macanan Jaya.

Suryabrata, S. 2010. Metodologi Penelitian. Jakarta: Raja Grapindo Persada.

Suhendar, T. 1986. Materi Pokok Berbicara Modul 1-3. Jakarta: Karunika.

Sumirat.2010. Penuntut Perkuliahan Bahasa Indonesia.Bandung: Alfabeta.

Tarigan. 1986. Berbicara I. Jakarta: Karunika Jakarta.

Tarigan, D.T.N. 1997. Pengembangan Keterampilan Berbicara. Jakarta: Depdikbud.

Tarigan,G. 1987. Berbicara Sebagai Suatu Keterampilan Berbahasa. Bandung: Angkasa. 